of resistance at the temperature of liquid hydrogen was made by Dewar on platinum, and he found that the resistance decreased to a certain value and then became constant. Thus from this result and from the behaviour of bismuth it is not altogether unexpected that a rather impure specimen of iron should show a definite turning power.

The present experiments, so far as they go, show that the resistance of iron at the temperature of $-253^{\circ}$ is actually greater than that at $-191^{\circ}$ (liquid air), a turning point on the curve occurring just below $-200^{\circ}$. Several readings were taken of the resistance of the iron spiral when immersed in liquid hydrogen, and the readings in liquid air were consistent with my previous results. But the observations lack confirmation, and I am induced to publish them owing to the small chance of getting any more liquid hydrogen until next year. E. PHILIP HARRISON.

University College, London, July $3 \mathrm{I}$.

\section{Retention of Leaves by Deciduous Trees.}

I HAVE read with much interest the various communications in NATURE on this subject, as the phenomenon was the subject of much conjecture to me last winter in Northumberland. "In one particular instance which I had constant opportunity of observing, the cause of the retention of the leaves could hardly have been "protection," as the beech hedge in question was in a very exposed, though by no means an elevated, situation. The hedge was a high one, probably 12 or 15 feet high, and formed a protection to the garden to the south or south-east of it, and in spite of the severe winds to which it was exposed it retained its leaves long after those of the beech trees of the neighbourhood had fallen.

I am inclined to think that it is much more probable that the frost theory brought forward by "P. T." in NATURE of Mayl 15 is the true solution of the phenomenon than that the retention is a " protective device."

It would be interesting to know whether "P. T." or any other readers of NATURE can produce any further proof of early frosts causing the premature drying up of the leaves in the case of beech hedges and young small trees. If, as "P. T." suggests, the early freezing prevents the formation of the abscission layer of cork at the base of the petiole, it should also cause the leaves of hedges and small trees to display their autumn tints, or at least to show signs of drying up earlier than the leaves of the larger trees.

If this can be shown to be generally the case where the leaves are retained, I think "P. T.'s" theory would be considerably strengthened.

Henzada, July I.

\section{Campanulate Foxgloves.}

IN the issue of NATURE for July 24 (p. 306) is a paragraph which is somewhat misleading. It is distinctly stated therein that " the terminal flower of each inflorescence was not a fox glove blossom, but a Canterbury bell (Campanula)," and again, "the combination of two flowers other than the forglove and Campanula, if it occurs, would, however, be worth recording." There is no telling what hybridisers may do in the future, but it is quite certain they have not yet succeeded in crossing the foxglove with a Campanula, nor does it seem likely they will ever accomplish such a feat. Bigeneric hybrids (if they are really bigeneric) are not uncommon nowadays, but the union is always between nearly allied genera, not between groups so widely different one from the other as the foxglove and the Canterbury bell. The confluence of several of the uppermost flowers of the foxglove into a large cup-shaped blossom is not uncommon. Indeed, the peculiarity is so far "fixed" that a large percentage of the seeds from this form may now be relied on to "come true." Is this a case of the inheritance of an acquired character?

The synanthic condition of the foxglove flowers is mentioned in my "Vegetable Teratology," p. 40 , or p. 59 of the German editions, and has repeatedly been recorded, but I am not aware that the cause of the deviation has been ascertained.

MAXWEll T. MASters.

Forestry.

IN my paper on forestry which appeared in NATURE of July 17 (p. 283) I was wrong in stating that cueilletes means "production of all kinds from baskets and fishing rods to sponges

NO. I 7 IO, vOL. 66] and caviare." The term means articles of forest produce, collected and utilised, though not specially made the object of the working of the forest.

Fruits and seeds, grasses, flowers, bark, medicinal products, and so on, all belong to cueilletes.

This correction is due to Mr. J. S. Gamble, F.R.S., who wrote the article in the Royal Scottish Arboricultural Society Proceedings, which I noticed in the paper referred to.

Coopers Hill, Englefield Green, Surrey. W. R. Fisher.

\section{THE FORTHCOMING MEETING OF THE BRITISH ASSOCIATION AT BELFAST.}

\section{Sectional Arrangements.}

THOUGH several of the sections of the British Association have not completed their programmes, it is possible to make a preliminary statement of some of the subjects to be brought before the Belfast meeting. Up to the time of going to press, the following particulars of sectional arrangements have reached us.

In Section A (Physics) there is to be a department in astronomy and cosmical physics, to be presided over by Prof. Schuster. To this department papers on the work on Eros, on the Moon and on Nova Persei will be presented, and some discussion on points connected with the nebular theory will, it is hoped, take place. Photographs from Yerkes Observatory will probably be shown, and several seismological communications will be made. In the section itself, Lord Rayleigh will probably raise the question of the conservation of weight in chemical reactions; Prof. Trouton will describe his experiments to detect the rotation of the ether with the earth, and Dr. Larmor will have something to say on the temperature of radiant energy. Belfast will be represented in the programme, Profs. Everett, Morton and Dixon having several communications to make.

The presidential address in Section C (Geology), by General C. A. McMahon, F.R.S., will deal with the general principles of rock metamorphism. Among the papers received or promised for the section are the following:-(r) "The Geology of the District around Belfast, including the Mourne Mountains"; (2) lecture on "The Structure of Ireland," by Prof. Grenville A. J. Cole; on "The Viscous Fusion of Rock-forming Minerals," by Prof. J. Joly, F.R.S. ; "List of Minerals known to occur in Ireland," by Mr. H. J. Seymour ; note on "The Scenery of Ceylon," by Mr. A. K. Coomaraswamy ; on "A Lower Carboniferous Fish-fauna from Victoria, Australia," by Dr. A. Smith Woodward, F.R.S.; on "The Graptolites of the Belfast District," by Mr. R. Clark ; on "The Valleys at the Head of the Hardanger Fjord, Norway," by Mr. H. W. Monckton ; on "The Marine Fauna of the Boulder Clay," by Mr. Joseph Wright; on "The Original Form of Sedimentary Deposits," by Rev. J. F. Blake ; on "A Stage in the Evolution of the Brittle Stars," by Prof. W. J. Sollas, F.R.S.; on "The Fishes of the Lower Devonian "Roofing Slate' of Gemünden, Germany," by Dr. R. H. Traquair, F.R.S.

Prof. Howes is president of Section D (Zoology) this year, and it is believed that he will devote his address to a general consideration of the importance of the morphological method in zoology. As regards the subsequent work of the section, several papers of a morphological and more or less technical character have already been promised. The president will show, on behalf of Dr. Hill, an interesting series of photographs of segmenting eggs and other early stages in the development of Dasyurus. Prof. Johnson Symington will read a paper on the "Cetacean Larynx." Prof. MacBride will describe the development of Echinus, and Mr. Bles, whose exhibit of living larvæ of Xenopus (Dactylethra) excited so much interest at the Royal Society's soirée 
recently, will give a general account of the development of this interesting frog. Mr. Graham Kerr will describe the result of his investigations on the early development of nerve and muscle in Lepidosiren.

It is hoped that Prof. Herdman will be able to contribute accounts illustrated by lantern of his recent experiences of "Dredging in the Indian Ocean" and "Life and Work on the Pearl-oyster Banks of the Gulf of Manaar." Several other papers from the Liverpool School are expected-by Mr. A. T. Watson, on a very interesting defensive mechanism which he has discovered in certain Onuphid worms ; by Mr. I. C. Thompson, on Indian Ocean Copepods collected by Prof. Herdman; and by Mr. H. C. Robinson, on his recent journeys in the East. Mr. J. Stanley Gardiner will read a paper on the "Bionomics of a Coral Reef."

The International Fisheries Investigation scheme, the inauguration of which is exciting so much interest at present, will form the subject of papers by Prof. McIntosh and Mr. Garstang. Of similarly economic interest will be Dr. J. L. Jameson's account of his reinvestigation of the problem of pearl formation. Mr. J. Stuart Thomson will give an account of his recent researches on the scales of marine fishes as an index of age.

Prof. Cossar Ewart will communicate the results of his recent experiments upon intercrossing of dogs. Prof. Weldon, in one of the evening lectures, will deal with heredity. This subject is so much "in the air" at present that it is to be hoped that some further communications dealing with it may be presented to the section. In regard to faunological matters, Dr. Scharff will read a paper on the "Atlantis Problem," Mr. Carpenter on the "Insect Fauna of Irish Caves," and Mr. Steel will make an interesting exhibit of Australian specimens.

Among the papers which, it has been arranged, will be read in Section E (Geography) are the following:-Dr. H. R. Mill, on "Antarctic Expeditions"; Dr. J. Milne, F.R.S., on "World-shaking Earthquakes in relation to Volcanic Eruptions in the West Indies"; on "The Jordan Valley" and on "Petra," by Prof. Libbey, of Princeton University, N.J.; Prof. Johnson, Dublin, on "Peat"; Mr. C. R. Beazley, on "Mythical Islands to the West of Ireland"; Mr. R. L. Praeger, of the National Library of Ireland, on "Geographical Plant Groups in the Irish Flora"; the Rev. W. S. Green, on "Rockall and Porcupine Bank off the West of Ireland"; Mr. J. Porter, on "The Cork Valleys"; Mr. R. B. Buckley, C.S.I., on "Colonisation and Irrigation in Uganda and the British East Africa Protectorate"; Captain Ryder, R.E., on "Surveys in Yünnan"; and Mr. C. H. Hawes, on "The Island of Sakhalin and its Inhabitants." The general subject of the presidential address by Sir Thomas $H$. Holdich will be "The Necessity for the Application of more Scientific Methods to Geographical Exploration."

The president of the Engineering Section is Prof. John Perry, F.R.S., whose presidential address is looked forward to with interest. In this section it is expected that an important report will be presented by the Committee on Road Traction. The committee, the secretary of which is Prof. H. S. Hele Shaw, was appointed two years ago to investigate certain questions connected with the propulsion of vehicles on roads. The introduction of motor cars has made these problems of great importance, and one easily realises that much has to be done, remembering that scientific engineering was born long after the railways had absorbed all important traffic from the roads. The Screw Gauge Committee reported last year that it was transferring its work to the National Physical Laboratory, and the progress of this will probably be reported this year. Among the papers to be read are several on Irish water questions, on problems connected with steam raising, on electrical and surveying apparatus and on some subjects of mechanical detail.

The president of Section K (Botany), Prof. J. R Green, F.R.S., will deal in his address with the present position of research in vegetable physiology and its importance in connection with agriculture. He will give a general account of some of the more important problems in this department of botany, and will endeavour to indicate certain lines of research which may be expected to have important developments in the future. The work of the section will include papers on "The Morphology and Past History of the Araucariez," by Mr. A. C. Seward, F.R.S., and Miss Sybille Ford; on "Internodes and their relation to Morphological Problems," by Prof. Percy Groom; on "The Dorsiventrality of the Podostomaceæ," by Mr. J. C. Willis ; on "The Function of the Nucleolus" and on "The Nucleus of the Cyanophycexe," by Mr. Harold Wager ; on "Sex in the Genus Diospyros" and on "Foliar Periodicity in Ceylon Trees," by Mr. H. Wright ; and on "Fossil Nipa Seeds from Belgium," by Mr. Seward and Mr. Arber.: Papers will also be read by Prof. Oliver and Miss Chick, Dr. Dixon, Miss Matthaei, Miss Bateson, Mr. Worsdell, Prof. Bottomley and others, and Mr. Thomas Steel will exhibit some characteristic Australian plants.

The president of Section L (Educational Science), Prof. Henry E. Armstrong, F.R.S., will deliver an address on the morning of Thursday, September II. The subjects to be brought forward in papers, addresses or reports with a view to discussion are :- "Recent Reforms in Irish Education, Primary and Secondary, with a view to their Coordination," by Dr. W. J. M. Starkie ; "Report on the Teaching of Mathematics"; Irish Educational Work: (I) "Intermediate Education in Ireland," by Mr. R. M. Jones; (2) "The Introduction of Practical Instruction into Irish National Schools," by Mr. W. Mayhowe Heller; "Technical Instruction in Relation to Industrial Development in Ireland," by the Right Hon. Horace Plunket; "Report on Teaching of Science in Elementary Schools" ; "The Training of Teachers," by Prof. Withers, Miss Walter and others; "Report on the Conditions of Health essential to the carrying on of the Work of Instruction in Schools" ; "The Subjects to be Taught as "Science" in Schools and the Order in which they should be Taken," by Dr. C. W. Kimmins ; papers on "Educational Experiments"; "The Teaching of English," by Mr. P. J. Hartog, Canon Lyttelton and others; joint discussion with Section G on "The Training of Engineers"; and "Interim Report on Examinations."

The Belfast Harbour Commissioners have offered to lend their steamer Musgrave to the local committee for the use of members of the Association for Harbour and Lough trips on three days during the meeting, and it was suggested that on one of these days a special visit of the Engineering Section might be made to the Harbour Works. Supplementary excursions are being arranged by the Belfast Naturalists' Field Club, consisting of short trips in the neighbourhood in the afternoons during the meeting, and also longer excursions for the Thursday after the meeting. Ample information respecting all these will be obtainable in the reception room. On Thursday, September II, the Lord Mayor of Belfast, Sir Daniel Dixon, D.L., will invite members, associates and holders of ladies' tickets to a reception in the exhibition hall near Queen's College. On Friday, September I2, the Earl of Shaftesbury invites members, associates and holders of ladies' tickets to a garden party in the grounds of Belfast Castle at the foot of Cave Hill at three p.m. (limited to 600). On Saturday evening, September 13 , Major Ritchie and Miss Ritchie will invite I 50 members to a reception at the Grove, at nine p.m. A list of lodgings and hotel accommodation has been prepared and may be obtained on application.

No. 17 IO, VOL. 66] 